\title{
Mutations that Affect Agrobacterium vitis-Induced Grape Necrosis also Alter Its Ability to Cause a Hypersensitive Response on Tobacco
}

\author{
T. C. Herlache, H. S. Zhang, C. L. Ried, S. A. Carle, D. Zheng, P. Basaran, M. Thaker, A. T. Burr, and T. J. Burr
}

First, second, third, fifth, sixth, eighth, and ninth authors: Department of Plant Pathology, NYSAES Cornell University, Geneva, NY 14456; second author: Department of Agronomy, Nanjing Agricultural University, Nanjing 210095, China; and fourth and seventh authors: Biology Department, Hobart and William Smith Colleges, Geneva, NY 14456.

Accepted for publication 13 July 2001.

\begin{abstract}
Herlache, T. C., Zhang, H. S., Ried, C. L., Carle, S. A., Zheng, D., Basaran, P., Thaker, M., Burr, A. T., and Burr, T. J. 2001. Mutations that affect Agrobacterium vitis-induced grape necrosis also alter its ability to cause a hypersensitive response on tobacco. Phytopathology 91:966-972.

Tn5-induced mutations in Agrobacterium vitis F2/5 resulted in both altered grape necrosis and tobacco leaf panel collapse phenotypes, suggesting that the underlying mechanisms of the reactions are related. The reaction on tobacco resembles the classical hypersensitive response (HR) caused by several plant pathogenic bacteria in that it is observable

within $14 \mathrm{~h}$, is inhibited by treatment of plants with metabolic inhibitors, and results in the inability to recover the pathogen from the necrotic zone. Strains of A. vitis differ with regard to their efficiency of causing the reaction on tobacco. An EcoRI fragment from one mutant, M6, which is necrosis-altered and HR-minus, was cloned and sequenced. Sequence analysis revealed that the $\operatorname{Tn} 5$ insertion occurred in a region that shares significant homology with genes involved in long chain fatty acid production by the marine bacteria Shewanella spp. and Moritella marina. Complementation of M6 with a cosmid clone from an F2/5 DNA library restored the tobacco HR and grape necrosis phenotypes.
\end{abstract}

Agrobacterium vitis is the primary causal agent of the economically important disease, crown gall of grape (7). A. vitis shows a high degree of natural host specialization because it is the primary Agrobacterium sp. found on grape and has been detected only in association with grapevines. Tumorigenic and nontumorigenic strains of $A$. vitis are commonly detected in galls, symptomless tissue, and in the grape rhizosphere. Tumorigenic strains form four major groups based on the structures of their Ti plasmids and on restriction analysis of specific regions of ribosomal DNA (23).

Interactions between $A$. vitis and its grape host are unusual in that the bacterium causes tumors on woody aerial parts of the vine and a host-specific necrosis on roots (6). Thus far, all tumorigenic and nontumorigenic strains have been shown to cause the necrotic reaction. Necrosis becomes apparent within 24 to $48 \mathrm{~h}$ following inoculation, and it is generally restricted to localized lesions. Although the necrosis causes rapid cell death, it resembles a disease reaction in that $A$. vitis is readily recovered from necrotic tissues. It was previously reported that grape necrosis is associated with polygalacturonase (PG) production by $A$. vitis (25). We assume, however, that other mechanisms are also involved because a pehA mutant of $A$. vitis was able to cause necrosis when grape tissues were inoculated with cell concentrations greater than approximately $10^{6} \mathrm{CFU} / \mathrm{ml}$ (16). Other researchers have also demonstrated that $A$. tumefaciens strains may cause necrosis on certain grape cultivars $(12,32)$. In these cases however, the response differs from that which we have reported in that it is grape genotype specific, is associated with specific Ti plasmid genes, and requires at least 1 week to develop.

In recent years, it has been demonstrated that several plant pathogenic bacteria that cause necrogenic diseases on host plants are able to induce a hypersensitive response (HR) on nonhosts (1). The HR results in rapid death of nonhost plant cells and con-

Corresponding author: T. J. Burr; E-mail address: tjb1@ cornell.edu

Publication no. P-2001-0816-02R

(C) 2001 The American Phytopathological Society siderable evidence indicates that it is part of the plants defense response against disease, thereby resembling apoptosis in animal systems (15). A. tumefaciens, which is generally nonnecrogenic on plants, has been reported to lack an HR induction system (24). In this paper, we identify $\operatorname{Tn} 5$ mutants of $A$. vitis that are altered in their ability to cause grape necrosis. We demonstrate that $A$. vitis causes a hypersensitive-like collapse on tobacco leaves and seven of nine necrosis-altered mutants are unable to cause the collapse, suggesting that the underlying mechanisms of both reactions are related. We provide evidence from one mutant that genes associated with necrosis and the HR may be involved in fatty acid biosynthesis.

\section{MATERIALS AND METHODS}

Bacterial strains and mutagenesis. Bacterial strains are listed in Table 1. A. vitis strains were propagated on potato dextrose agar (PDA) (Difco Laboratories, Detroit) at $28^{\circ} \mathrm{C}$. Tn 5 mutagenesis of strain F2/5 was accomplished through conjugal mating with $E s$ cherichia coli S17-1(pSUP2021) (27) as previously described (9). Mutants were selected on AB minimal medium (11) amended with kanamycin $(50 \mu \mathrm{g} / \mathrm{ml})$, restreaked on the same medium to exclude auxotrophs, and maintained on PDA plus kanamycin. E. coli was grown on Luria-Bertani (LB) agar (26) with appropriate antibiotics at $37^{\circ} \mathrm{C}$. The optical densities of bacterial suspensions were determined with a spectrophotometer (Spectronic 20; Spectronic Instruments Inc., Rochester, NY), and populations of cells at the various optical densities were determined by dilution plating.

Tn5 mutants. Approximately 2,000 Tn 5 mutants of strain F2/5 were screened for their ability to elicit necrosis on Vitis vinifera cv. Chardonnay green shoot explants. Explants were excised from greenhouse-grown vines and surface-disinfected with a $50 \%$ ( vol/vol) solution of bleach in distilled water for $20 \mathrm{~min}$ followed by $70 \%$ ethanol for $5 \mathrm{~min}$. They were rinsed in sterile distilled water (SDW) and cut into approximately $1 \mathrm{~cm}$ long sections. Explants were supported vertically, with their basal end up, in $10 \%$ water agar plates, and their aerial ends were inoculated with $2 \mu \mathrm{l}$ 
of an optical density at $600 \mathrm{~nm}\left(\mathrm{OD}_{600}\right)=1.0$ suspension of the mutants (approximately $1.0 \times 10^{9} \mathrm{CFU} / \mathrm{ml}$ ). Development of necrosis was scored over a period of 5 days. F2/5 was inoculated as a positive and distilled water as a negative control. Mutants that caused necrosis differing from the wild type were retested.

All mutants with altered necrosis were inoculated on shoot explants of $V$. vinifera cv. Chardonnay, V. labrusca cv. Niagara, and $V$. riparia. Ten explants of each species were inoculated with each mutant and F2/5, and the experiment was repeated. Assays for PG production by bacteria were done as previously described (25).

To determine whether single Tn5 insertions occurred in the mutants, total bacterial DNA was prepared (8). DNA from each mutant $(10 \mu \mathrm{g})$ were digested to completion with EcoRI and ClaI (do not cut within the transposon) and transferred to a Nytran membrane according to the TurboBlotter protocol (Schleicher \& Schuell Inc., Keene, NH). Bacterial DNA was probed with a 4.6-kb HindIII fragment that was cut from Tn5 in pSUP2021. The probe was labeled with ${ }^{32} \mathrm{P}[\mathrm{dCTP}]$ using a labeling system (Primea-Gene; Promega Corp., Madison, WI) following the manufacturer's protocol. Prehybridization was carried out in a solution of $50 \%$ formamide, $0.5 \%$ sodium dodecyl sulfate (SDS), $5 \times$ Denhardt's solution (26), $6 \times \mathrm{SSC}(1 \times \mathrm{SSC}$ is $0.15 \mathrm{M} \mathrm{NaCl}$ plus $0.015 \mathrm{M}$ sodium citrate), and $100 \mu \mathrm{g} / \mathrm{ml}$ of denatured salmon sperm DNA at $42^{\circ} \mathrm{C}$ in a hybridization oven (Hybaid Mini-4; Hybaid Instruments, Holbrook, NY). Hybridization was performed by adding denatured ${ }^{32} \mathrm{P}$-labeled probed into prehybridization solution at $42^{\circ} \mathrm{C}$ overnight. The DNA blot was washed with $2 \times$ SSC and $0.5 \%$ SDS at room temperature for $5 \mathrm{~min}, 1 \times \mathrm{SSC}$ and $1 \% \mathrm{SDS}$ at room temperature for $15 \mathrm{~min}$, and $0.1 \times \mathrm{SSC}$ and $1 \%$ $\mathrm{SDS}$ at $68^{\circ} \mathrm{C}$ for $30 \mathrm{~min}$.

Tobacco HR assays. Nicotiana tabacum cv. Xanthi plants were maintained in the greenhouse. Leaf panels of fully expanded leaves were infiltrated through a pin puncture by a needleless syringe (30), with cultures of bacteria grown for 18 to $24 \mathrm{~h}$ at $28^{\circ} \mathrm{C}$ on PDA or PDA amended with kanamycin. Prior to infiltration, bacteria were suspended in SDW to an $\mathrm{OD}_{600}=1.5$ (approximately $\left.5.0 \times 10^{9} \mathrm{CFU} / \mathrm{ml}\right)$. In addition to $\mathrm{F} 2 / 5$ and the necrosis mutants, a group of nontumorigenic and tumorigenic $A$. vitis strains was tested for HR-inducing ability.

Growth of mutants in vitro and in planta. Growth rates of F2/5 and mutants were tested in half-strength potato dextrose broth (PDB). The bacteria were initially suspended to $\mathrm{OD}_{600}=0.1$ (approximately $1.0 \times 10^{8} \mathrm{CFU} / \mathrm{ml}$ ) in SDW and diluted 10 -fold in broth. Cultures were incubated on a shaker at room temperature, and growth was determined by measuring optical density at hourly intervals.

Growth of mutants M6, M675, and M852 were compared with F2/5 on grape. Bacteria were grown for $48 \mathrm{~h}$ on PDA or PDA amended with kanamycin and suspended to $\mathrm{OD}_{600}=0.1$ in SDW. Suspensions were diluted 100-fold (approximately $1.0 \times$ $10^{6} \mathrm{CFU} / \mathrm{ml}$ ), and $2 \mu \mathrm{l}$ was applied to the cut ends of cv. Chardonnay shoot explants according the method described previously.

TABLE 1. Agrobacterium strains

\begin{tabular}{|c|c|c|c|}
\hline Species, strain & Isolated from & Phenotype/Ti type & Reference/source \\
\hline A. vitis, $\mathrm{C}$ & gall & 101 & T. Burr, NY, 1979 \\
\hline A. vitis, $\mathrm{C}$ & vinifera gall & Tumorigenic/vit & T. Burr, NY, 1999 \\
\hline A. vitis, CG412 & Vineyard soil & Tumorigenic/oct & T. Burr, NY, 1983 \\
\hline A. vitis, 22-9 & $V$. riparia & rigenic & T. Burr, NY, 1999 \\
\hline A. vitis, CG523 & V. riparia & Non & T. Burr, NY, 1999 \\
\hline A. vitis, CG556 & $V$. riparia & Non & This paper \\
\hline A. vitis, $\mathrm{F} 2 / 5$ & $V$. vinifera gall & Nontumorigenic & (28) \\
\hline $\begin{array}{l}\text { A. tumefaciens, } \\
\text { C58 }\end{array}$ & Cherry gall & Tumorigenic/nop & (34) \\
\hline $\begin{array}{l}\text { A. rhizogenes, } \\
\text { CG978 }\end{array}$ & $\begin{array}{l}\text { Pussy willow } \\
\text { gall }\end{array}$ & Tumorigenic & T. Burr, NY, 1986 \\
\hline
\end{tabular}

a Defines Ti plasmid type based on presence of opine synthase genes: nop = nopaline, oct $=$ octopine/cucumopine, and vit $=$ vitopine.
Bacterial suspensions were dilution plated to verify actual numbers inoculated to grape shoots. Five explants were assayed beginning $12 \mathrm{~h}$ after inoculation. The entire explant was triturated in $1 \mathrm{ml}$ of SDW in an Eppendorf tube. Suspensions were dilution plated on PDA plus trimethoprim $(20 \mu \mathrm{g} / \mathrm{ml})$, and A. vitis colonies were counted after $48 \mathrm{~h}$ of growth at $28^{\circ} \mathrm{C}$. Trimethoprim was used to suppress growth of nontarget bacteria.

Populations of F2/5 and a necrosis-altered HR-minus mutant (M6) were determined after infiltration into tobacco leaves. At $0.25,24,48$, and $72 \mathrm{~h}$ postinfiltration, 7-mm-diameter tissue samples from completely within the infiltrated areas were collected with a cork borer. Three samples for each strain were collected from different plants at each time interval. Samples were placed individually in $1 \mathrm{ml}$ of SDW in Eppendorf tubes, triturated, and dilution plated on PDA amended with trimethoprim. Colonies were counted after $48 \mathrm{~h}$, and all experiments were repeated.

Characterization of $\boldsymbol{A}$. vitis-induced HR in tobacco. F2/5 was grown on PDA and in induction medium containing $0.5 \mathrm{mM}$ $\mathrm{K}_{2} \mathrm{SO}_{4}, 0.5 \mathrm{mM} \mathrm{CaCl}, 5.0 \mathrm{mM}$ morpholineethanesulfonic acid (MES), $175 \mathrm{mM}$ mannitol, and $5 \mathrm{mM}\left(\mathrm{NH}_{4}\right)_{2} \mathrm{SO}_{4}$ adjusted to $\mathrm{pH}$ 7.0. Induction medium was previously reported to induce expression of hypersensitivity and pathogenicity ( $h r p$ ) genes of Erwinia amylovora (31). Cells from both media were suspended in $\mathrm{SDW}$ to $\mathrm{OD}_{600}=1.5$, and the minimum population that was able to cause the HR was determined by infiltrating leaves with twofold serial dilutions of the bacterial suspension. At least six leaf panels per two plants were infiltrated, and the experiment was repeated several times.

Infiltration buffers also affect the number of bacterial cells required to cause the HR (22). To test this variable, F2/5 was grown

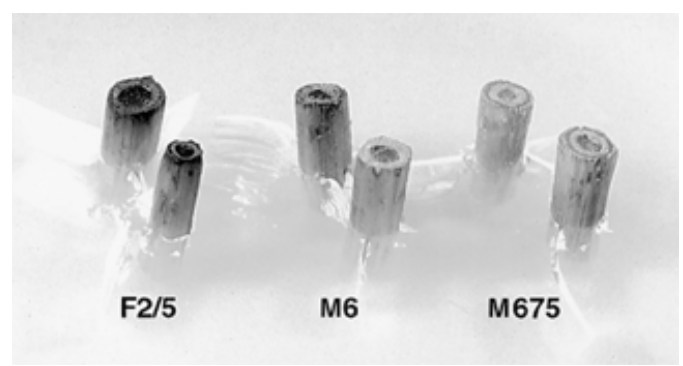

Fig. 1. Necrosis phenotypes of wild-type F2/5 and Tn 5 mutants M6 (reduced necrosis) and M675 (no necrosis) on Vitis vinifera cv. Chardonnay shoot explants.

TABLE 2. Necrosis phenotypes of F2/5 mutants on different Vitis spp. and hypersensitive response (HR) phenotypes of these mutants on Nicotiana tabacum cv. Xanthi

\begin{tabular}{lcccc}
\hline & \multicolumn{2}{c}{ No. of explants with different necrosis ratings } & \\
\cline { 2 - 3 } Strain & V. vinifera & V. labrusca & V. riparia & HR/PG \\
\hline F2/5 & $14-6-0$ & $18-2-0$ & $14-6-0$ & $+/+$ \\
M6 & $2-18-0$ & $13-7-0$ & $4-16-0$ & $-/+$ \\
M675 & $0-0-20$ & $0-0-20$ & $0-0-20$ & $-/+$ \\
M816 & $12-3-5$ & $15-3-2$ & $8-5-7$ & $+/+$ \\
M832 & $3-6-11$ & $11-7-2$ & $2-4-14$ & $+/+$ \\
M852 & $10-8-2$ & $17-2-1$ & $13-5-2$ & $-/+$ \\
M901 & $7-13-0$ & $19-1-0$ & $5-14-1$ & $-/+$ \\
M1123 & $15-4-1$ & $7-13-0$ & $6-11-3$ & $-/+$ \\
M1154 & $0-0-20$ & $0-8-12$ & $0-0-20$ & $-/+$ \\
M1320 & $6-10-4$ & $11-6-3$ & $3-10-7$ & $-/+$ \\
\hline
\end{tabular}

a Table shows combined results from four independent experiments in which five shoot explants were inoculated with each bacterium. First number indicates shoots that showed black necrosis, second number are those with reduced brown-colored necrosis, and third is the number that showed no necrosis.

${ }^{\mathrm{b}}+=$ ability to induce collapse of tobacco leaf panels (HR) and to produce polygalacturonase (PG).

c Mutant 832 induced collapse in about $10 \%$ of infiltrated leaf panels. 
overnight on PDA, suspended to $\mathrm{OD}_{600}=1.5$ in SDW, in $5 \mathrm{mM}$ phosphate buffer ( $\mathrm{pH} 5.5$ ), in $5 \mathrm{mM}$ MES buffer ( $\mathrm{pH}$ 5.5), and in PDB. Twofold dilutions of the bacterium in each medium were infiltrated into tobacco leaf panels. The experiment was repeated several times.

Because the HR initiated by several plant pathogenic bacteria is an active response by the plant, it can be blocked with inhibitors of metabolism and signal transduction (14). We tested the effects of inhibitors on the ability of A. vitis to cause tobacco leaf collapse. The inhibitors included sodium orthovanadate $\left(5 \times 10^{-5} \mathrm{M}\right)$, a general ATPase/phosphatase inhibitor, cobalt chloride $\left(5 \times 10^{-4} \mathrm{M}\right)$, a calcium channel blocker, and cycloheximide $\left(7.1 \times 10^{-5} \mathrm{M}\right)$, an inhibitor of $80 \mathrm{~S}$ ribosomes. Inhibitors were infiltrated into tobacco leaf panels about $1 \mathrm{~h}$ prior to infiltration with a suspension of F2/5 $\left(\mathrm{OD}_{600}=1.5\right.$ in SDW $)$. Leaves infiltrated with SDW were used as a control. All experiments were repeated at least once. The effect of the inhibitors on viability of F2/5 was determined by measuring growth of the bacterium in PDB amended with the same concentrations of inhibitors that were infiltrated into the plants.

Genomic library construction. F2/5 genomic DNA was isolated, resulting in a concentration of approximately $1.4 \mu \mathrm{g} / \mu \mathrm{l}$. DNA from cosmid vector pZL1 (20) was purified (QIAfilter Midi; Qiagen, Valencia, CA) according to the Qiagen Plasmid Purification Handbook, resulting in a final concentration of approximately $0.2 \mu \mathrm{g} / \mu \mathrm{l}$. Genomic DNA was partially digested for $1 \mathrm{~h}$ at $37^{\circ} \mathrm{C}$, with Sau3AI at a concentration of 0.01 units, resulting in fragments of approximately $40 \mathrm{~kb}$. The DNA was ligated to BamHIdigested pZL1 DNA that had been treated with alkaline phosphatase. The ligation mixture was packaged into phage 1 using the Packagene system (Promega) and transduced into E. coli LE392.

Cloning and sequencing of M6. One of the necrosis-altered HR-minus mutants (M6) was grown in $50 \mathrm{ml}$ of PDB amended with kanamycin overnight at $28^{\circ} \mathrm{C}$. E. coli $\mathrm{DH} 5 \alpha$ (pBluescript SK-) was grown in $50 \mathrm{ml}$ of Terrific broth (26) amended with $100 \mu \mathrm{g}$ of ampicillin per $\mathrm{ml}$ overnight at $37^{\circ} \mathrm{C}$.

Total DNA was prepared as described for Southern blots. pBluescript DNA was prepared according to the alkaline-lysis protocol (26). Ten micrograms of DNA from M6 and pBluescript was cut to completion with EcoRI, phenol-chloroform extracted, and precipitated with $2 \mathrm{vol}$ of $95 \%$ ethanol and $0.2 \mathrm{vol}$ of $7.5 \mathrm{M}$ ammonium acetate. Aliquots of separately digested DNAs were mixed in a 3:1 ratio (M6 to pBluescript) and ligated for $4 \mathrm{~h}$ with T4 DNA ligase (Promega) at room temperature. Twenty microliters of the ligation reaction was used to transform E. coli JM109 competent cells by heat shock (Promega). The transformation reaction was inoculated in $15 \mathrm{ml}$ of Terrific broth amended with kanamycin and ampicillin to select for E. coli transformants. Ampicillin- and kanamycin-resistant bacteria were dilution plated on LB agar amended with ampicillin, kanamycin, $50 \mu \mathrm{g}$ of X-gal per $\mathrm{ml}$, and $100 \mu \mathrm{g}$ of isopropyl- $\beta$-D-thiogalactopyranoside per $\mathrm{ml}$ and were grown at $27^{\circ} \mathrm{C}$ for $48 \mathrm{~h}$. Plasmid DNA from selected strains was purified according to the alkaline-lysis protocol. A sample (approximately $500 \mathrm{ng}$ ) of each plasmid was digested with EcoRI and separated on a $0.7 \%$ agarose gel to both verify the presence of insert DNA and to determine insert size.

The M6 clone was sequenced using the M13 primer annealing sites on the vector, and further by primers designed to M6 partial sequences. Sequencing was performed at Cornell University, NY, on an ABI model 370 DNA sequenator. Sequence reactions used Taq DNA polymerase. Sequence data were analyzed using the DNAstar DNA analysis software package (DNAstar, Madison, WI). Homologous sequences in the NCBI database were identified using the BlastX program. Sequence analysis was further verified by sequencing the EcoRI fragment cut from cosmid 3VT5 that hybridized with a probe made from sequence generated from the M6 restriction fragment.

Complementation of M6. Primers designed from DNA sequence existing on opposite sides of the $\mathrm{Tn} 5$ insertion in M6 were used to amplify a 750-bp region from F2/5 that was subsequently labeled and used to probe the F2/5 genomic library. Cosmids that hybridized to the probe were screened by polymerase chain reaction (PCR) to verify the presence of the M6 sequences of interest. Cosmid 3VT5 was transformed into E. coli S17-1 and transferred by conjugation to M6. This was accomplished by streaking S17-1 (3VT5) together with M6 on $\mathrm{AB}$ minimal medium containing kanamycin and ampicillin. M6 transformants were verified as

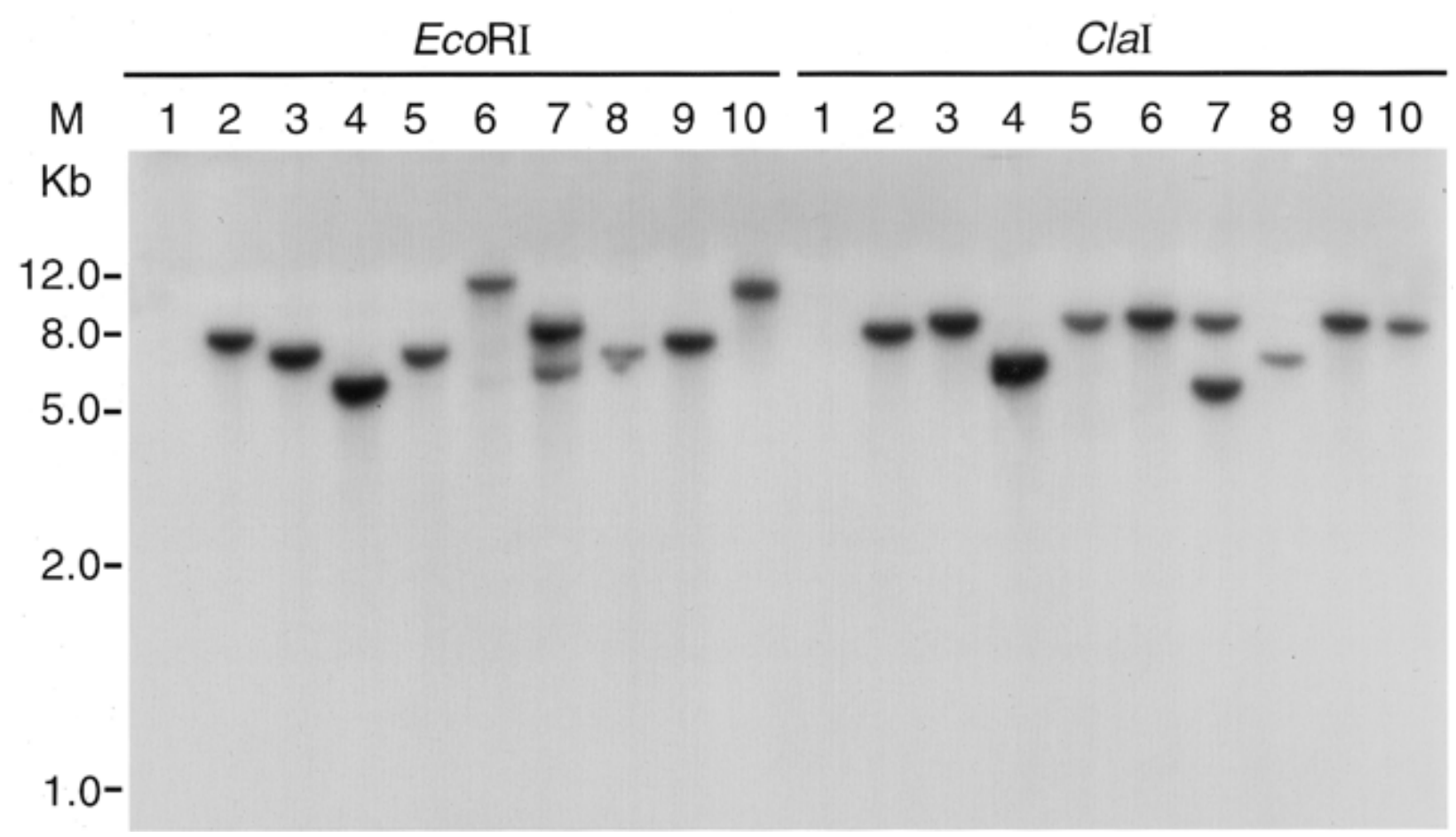

Fig. 2. Southern blot of EcoRI- and ClaI-digested DNA from F2/5 and Tn5 mutants probed with a 4.6-kb fragment from Tn5 in pSUP2021. Lanes 1 to 10 correspond to strains F2/5, M6, M675, M816, M832, M852, M901, M1123, M1154, and M1320, respectively. M indicates a 1-kb DNA ladder. 
carrying 3VT5 by PCR. This was done using the primers described previously. A 750-bp product was detected from M6(3VT5) but not from M6 because of the presence of Tn5.

It was determined by dilution plating M6(3VT5) from culture and from grape explants $48 \mathrm{~h}$ after inoculation that about 10 -fold fewer cells grew on PDA amended with kanamycin and ampicillin (PDA-K-A) than on nonamended medium (data not shown), suggesting that the cosmid is not highly stable in M6. Therefore, to conduct complementation assays, single, relatively large colonies of M6(3VT5) growing on PDA-K-A for 24 to $36 \mathrm{~h}$ were suspended in $20 \mu \mathrm{l}$ of $200 \mu \mathrm{g}$ of ampicillin per $\mathrm{ml}$ and spotted back on PDA-K-A. Those that produced abundant growth overnight were suspended in SDW and were tested for ability to induce HR and necrosis. Controls included a suspension of kanamycin and ampicillin alone and M6 made to the same concentration as the complemented bacteria.

\section{RESULTS}

Isolation of $\boldsymbol{A}$. vitis grape necrosis mutants. Nine mutants were identified that caused altered necrosis phenotypes on grape (Fig. 1). Whereas F2/5 causes a black necrosis with ooze within $72 \mathrm{~h}$, the mutants caused less (brown in color with less or no ooze) or no necrosis. Severity of necrosis for some mutants differed depending on the grape genus on which they were inoculated (Table 2). For example, mutant M901 produced necrosis similar to wild-type F2/5 on V. labrusca, but much less on the other species. Only one mutant, M675, was necrosis-negative on all three Vitis spp. Southern blots indicated that all of the mutants except M901 carry a single Tn 5 insertion in that only one hybridizing band is apparent after digestion with EcoRI and ClaI (Fig. 2). All mutants produced clear zones on PG-agarose gels ( $\mathrm{pH} 4.5)$ indicating the production of PG (Table 2).

HR caused by $A$. vitis and necrosis-altered mutants. All $A$. vitis strains induced a hypersensitive-like collapse on tobacco, however, at variable frequencies (Fig. 3; Table 3). A. tumefaciens C58 and A. rhizogenes CG978 never caused tobacco tissue collapse. Seven of the nine necrosis-altered F2/5 mutants exhibited an HR-minus phenotype, i.e., only mutant 816 caused the HR at the same frequency as F2/5, and mutant 832 caused the HR in approximately $10 \%$ of infiltrated leaf panels (Table 2 ).

Growth of mutants. All of the mutants grew at rates similar to F2/5 in half-strength PDB, except 832, which grew more slowly (data not shown). Mutants M6, M675, and M852 grew at rates similar to F2/5 on grape explants (Fig. 4). Populations of the mutants on explants were not significantly different from F2/5 by 72-h postinoculation. In contrast, when tobacco leaf panels were infiltrated with F2/5 and M6, viable F2/5 cells could not be detected in the collapsed leaf tissue at $72 \mathrm{~h}$, whereas the M6 population increased over the same time period (Fig. 5).

Characterization of HR. Tissue collapse following infiltration of tobacco leaves with F2/5 was obvious within $14 \mathrm{~h}$, and the infiltrated regions became dry and brown within $48 \mathrm{~h}$. The minimum cell concentration of F2/5 that caused collapse after growth on PDA or in induction medium was approximately $5.0 \times 10^{8} \mathrm{CFU} / \mathrm{ml}$. At this concentration, $33 \%$ of the infiltrated leaf panels developed the reaction, whereas at $5.0 \times 10^{9} \mathrm{CFU} / \mathrm{ml},>90 \%$ (usually $100 \%$ ) exhibited the HR-like phenotype.

When cells of F2/5 were grown on PDA and then suspended in SDW, $5 \mathrm{mM}$ phosphate buffer ( $\mathrm{pH}$ 5.5) or in $5 \mathrm{mM}$ MES buffer (pH 5.5), a concentration of approximately $5.0 \times 10^{9} \mathrm{CFU} / \mathrm{ml}$ was required for HR induction in $>90 \%$ of infiltrated leaf panels. However, when the cells were suspended in PDB, only approximately $5.0 \times 10^{8} \mathrm{CFU} / \mathrm{ml}$ were required to induce the reaction at the same frequency.

Tobacco tissue collapse was reduced by pretreatment of leaf panels with metabolic inhibitors; however, cycloheximide was less inhibitory than the others (Table 4). Twelve of twenty-one cycloheximide-treated panels developed a reduced or no HR, whereas 19 and 21 of the panels had reduced or no HR with

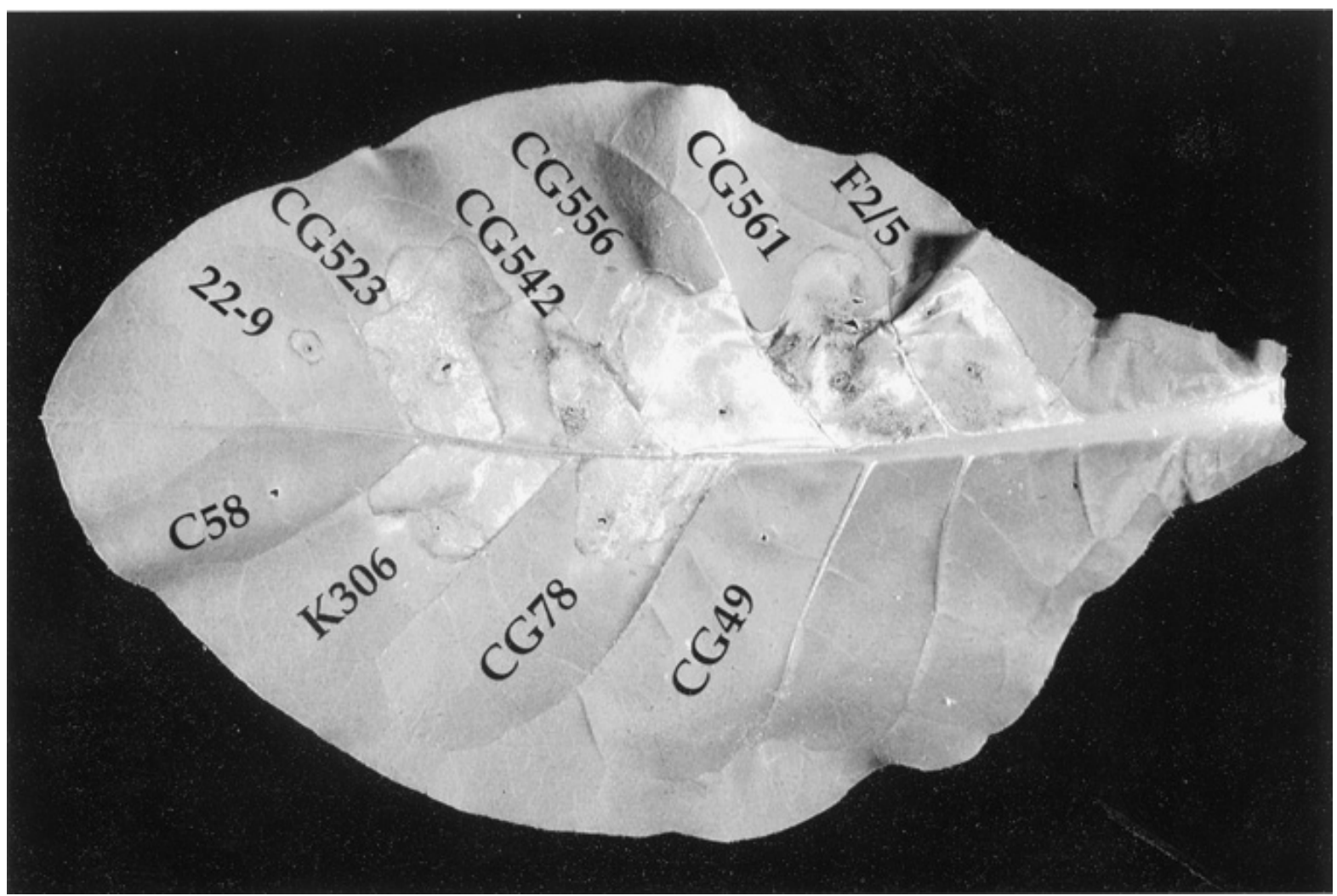

Fig. 3. Hypersensitive response-like collapse of tobacco leaf panels induced by a diverse group of Agrobacterium vitis strains. Strains are designated on the leaf panels. 
orthovanadate and cobalt chloride, respectively. Cycloheximide at concentrations greater than $7.1 \times 10^{-5} \mathrm{M}$ was phytotoxic to tobacco leaves. F2/5 cell numbers remained unchanged over a 24-h period in media amended with $5.0 \times 10^{-4} \mathrm{M}$ cobalt chloride, whereas the bacteria grew when suspended in the other inhibitors. Therefore, the inhibitors are not lethal to F2/5 at the concentrations tested and their HR-blocking effects are most likely due to inhibition of plant metabolism. Infiltration of panels with water $1 \mathrm{~h}$ prior to bacteria did not effect the development of the HR.

Sequence analysis of M6. The M6 EcoRI fragment (3,107 bp without Tn5) was sequenced (GenBank Accession No. AF326779). One complete and one partial open reading frame (ORF) that share significant homology with genes in the NCBI database were identified using the BlastX program (Fig. 6). Both ORFs are homologs of genes found in fatty acid operons of the marine bacteria Shewanella spp. and Moritella marina $(33,29)$.

Complementation of M6. Fifteen cosmids in the F2/5 gene bank exhibited some level of hybridization with the 750-bp M6 probe. When screened by PCR, one (3VT5) consistently yielded the 750-bp PCR product. Cosmid 3VT5 was transferred to S17-1 by heat shock and subsequently to M6 by conjugation. Complemented M6 strains were infiltrated into tobacco and were able to induce a typical HR, although sometimes delayed compared with the wild type. In initial experiments, M6(3VT5) did not complement the grape necrosis phenotype when bacterial growth was taken directly from a PDA-K-A plate. However, if single colonies

TABLE 3. Frequency of hypersensitive response induction by different bacterial strains on Nicotiana tabacum cv. Xanthi

\begin{tabular}{lcc}
\hline Strain & Species/tumorigenicity & \% Leaf panels with collapse ${ }^{\mathrm{a}}$ \\
\hline F2/5 & vitis/- & 100 \\
CG523 & vitis/- & 88 \\
CG556 & vitis/- & 100 \\
CG49 & vitis/+ & 22 \\
CG78 & vitis/+ & 67 \\
CG412 & vitis/+ & 33 \\
CG978 & rhizogenes/+ & 0 \\
C58 & tumefaciens/+ & 0
\end{tabular}

${ }^{\mathrm{a}}$ Leaf panels were infiltrated with bacterial concentrations of approximately $1.5 \times 10^{9} \mathrm{CFU} / \mathrm{ml}$. Results were calculated from at least 24 leaf panels that were infiltrated with each bacterial strain.

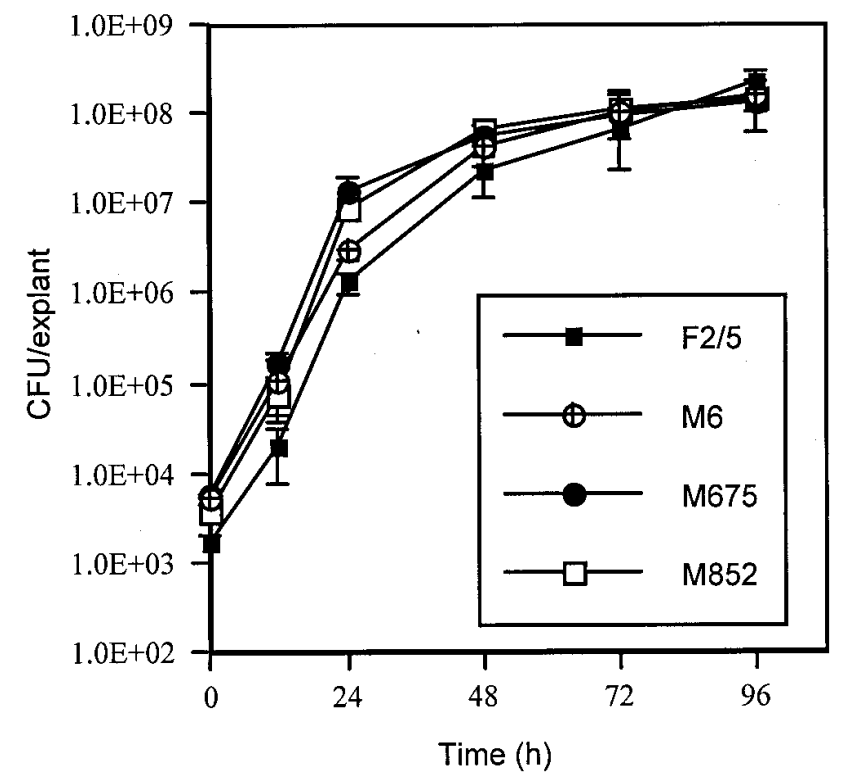

Fig. 4. Growth of F2/5 and mutants on grape shoot explants. Five explants, inoculated with each bacterium, were analyzed at each time. A one-way analysis of variance indicated that by $72 \mathrm{~h}$ none of the populations of the bacteria on explants were significantly different $(P=0.05)$. were first suspended in ampicillin as described previously, the phenotype was complemented.

\section{DISCUSSION}

A. vitis shows a high level of host specificity in that it has only been isolated from grapevines and associated soil (7). Its interaction with grape is unusual in that it causes the debilitating crown gall disease on woody trunks and canes of the vine and a localized necrosis on grape roots. Necrosis resembles a disease reaction in that the bacterium is readily isolated from necrotic tissues of roots as well as from inoculated grape seedling hypocotyls and shoot explants (6). The production of PG by A. vitis is reported to be one factor associated with grape necrosis; however, others must also be involved (16). In this paper, we have demonstrated that single gene mutations can alter or completely eliminate the ability of $A$. vitis to cause grape necrosis and an HR-like collapse of tobacco leaves; however, the same mutations do not result in loss of PG production.

Necrosis of grape tissues may also be caused by certain $A$. tumefaciens strains. In these cases, the Ti plasmid gene virC from pTiA6 (32) and T-DNA genes tms and 6b from pTiBo542 (12) are associated with the necrosis phenotype. This Ti plasmid-associated necrogenesis differs from that caused by A. vitis in that it is restricted to a few Vitis genotypes and requires a significantly longer period following inoculation before symptoms are observed ( 1 week compared with $48 \mathrm{~h}$ ). The A. vitis necrosis was expressed on all Vitis spp. that were evaluated, and is caused by tumorigenic and nontumorigenic strains, some with no detectable plasmids.

It is particularly interesting that $A$. vitis is able to cause an HRlike collapse of tobacco leaves that is similar to the HR that is induced by several other plant pathogenic bacteria. HR induction by plant pathogenic bacteria is thought to be part of the plants defense against disease $(19,30)$ and is an active response by the plant that has similarities to apoptosis in animal systems $(15,17)$. Like apoptosis, the HR requires activation of signal-transduction cascades in the plant and de novo gene expression. The A. vitis reaction is noticeable on tobacco leaf panels within $14 \mathrm{~h}$ of infiltration and becomes dry and brown within 24 to $48 \mathrm{~h}$. Like the HR of other bacteria, the response is inhibited by preinfiltration of leaves with different inhibitors of plant metabolism, indicating that the plant plays an active role in the expression of cell death. The reaction also resembles a defense response because the pathogen $(\mathrm{F} 2 / 5)$ cannot be recovered from infiltrated zone following collapse. Other hallmarks of the classical HR, such as up-

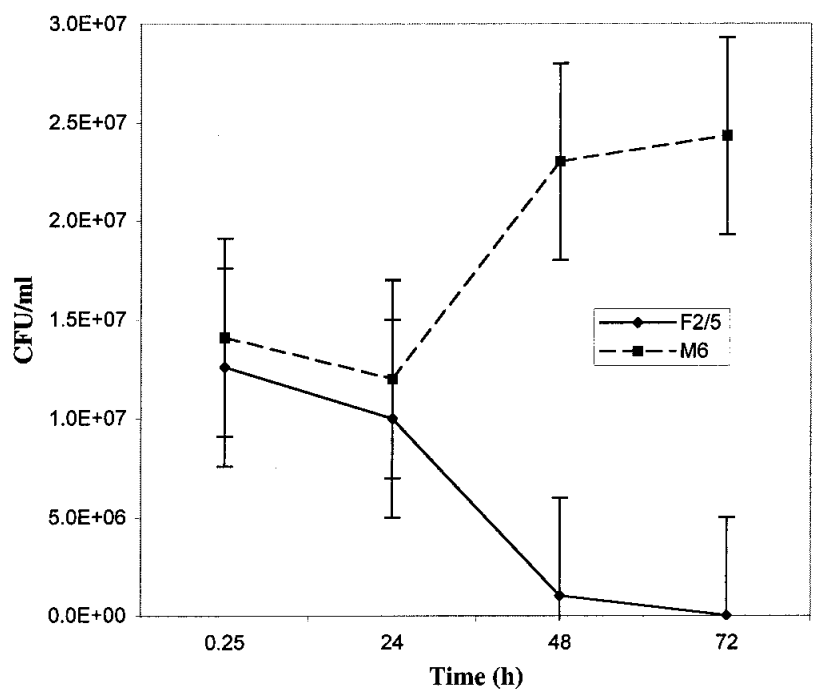

Fig. 5. Population of F2/5 and M6 after infiltration of tobacco leaf panels. Leaves were infiltrated and populations were determined. 
regulation of well-known pathogenesis-related genes in nonhost plants (15), have yet to be determined.

Induction of tobacco leaf collapse by $A$. vitis appears to require a greater cell concentration than what is needed by Erwinia amylovora or Pseudomonas syringae, but similar to that of other bacteria. The gram-positive bacterium Clavibacter michiganensis subsp. sepedonicus requires $1.3 \times 10^{9} \mathrm{CFU} / \mathrm{ml}$ for the HR (22), and the nonmacerogenic out-mutant Erwinia chrysanthemi requires approximately $5.0 \times 10^{8} \mathrm{CFU} / \mathrm{ml}$ (2). The difference in cell numbers for induction of the response may indicate that the conditions we used for growing the bacterium are not optimal for elicitor production. Elicitors may differ in how effectively they signal the induction of an HR. It is also possible that high cell concentrations are required because elicitor or secretory genes are regulated in a density-dependent manner. Like Erwinia amylovora, growth media and suspension buffers may affect HR gene expression (31). We have determined that a significantly lower concentration of cells is required to induce the response if they are suspended in PDB. Further studies on parameters that affect expression of HRassociated genes in A. vitis are necessary. Our results, however, demonstrate that the $A$. vitis-induced collapse does not result from a general toxic response caused by high densities of bacterial cells because seven of nine mutant strains never caused a response. This was true even when leaves were infiltrated with the mutants at concentrations greater than $5.0 \times 10^{9} \mathrm{CFU} / \mathrm{ml}$ (data not shown).

It was previously reported that $A$. tumefaciens does not induce an HR and that infiltration of tobacco with tumorigenic A. tumefaciens or $P$. syringae pv. savastanoi inhibits the HR caused by $P$. syringae pv. phaseolicola (24). In this case, inhibition was dependent on the presence of functional tms genes. We also found that $A$. tumefaciens and $A$. rhizogenes do not induce the HR on tobacco. Recently, however, it was reported that certain Agrobacterium strains induced a necrosis of specific maize lines (13). The necrosis resembled an apoptotic response and the affected maize DNA was cleaved into oligonucleosomal fragments and the response was inhibited in lines transformed with genes that encode caspase inhibitors. These results suggest that A. tumefaciens may carry genes that trigger an HR-like response when expressed in the proper plant environment.

Our results show that certain strains of $A$. vitis are less efficient at causing collapse of leaf panels than others. In general, tumorigenic strains were less efficient at causing the HR than nontumorigenic strains. It may be that like A. tumefaciens in tobacco, the expression of certain T-DNA genes are inhibitory to HR development. Possibly, tumorigenic strains have evolved toward a reduced HR-eliciting ability to avoid killing plant cells that are targeted for transformation (and subsequent crown gall disease). Further analyses with additional strains that carry an array of Ti plasmid types are needed before it can be concluded that expression of T-DNA genes, or the transformation event, is in some way suppressing the HR by A. vitis.

TABLE 4. Effect of plant metabolic inhibitors on Agrobacterium vitisinduced collapse of tobacco leaf panels

\begin{tabular}{lcccc}
\hline & & \multicolumn{3}{c}{ Hypersensitive response } \\
\cline { 3 - 5 } Inhibitor $^{\mathrm{a}}$ & Concentration & Positive & Intermediate & Negative \\
\hline Cobalt chloride & $5.0 \times 10^{-4} \mathrm{M}$ & 0 & 2 & 19 \\
Orthovanadate & $5.0 \times 10^{-5} \mathrm{M}$ & 2 & 6 & 13 \\
Cycloheximide & $7.1 \times 10^{-5} \mathrm{M}$ & 9 & 8 & 4 \\
No inhibitor & $\ldots$ & 21 & 0 & 0 \\
\hline
\end{tabular}

${ }^{\mathrm{a}}$ Inhibitor solutions were infiltrated into the leaf, and bacteria were not infiltrated until watersoaking was no longer apparent (approximately $1 \mathrm{~h}$ ).

b Total responses from three independent experiments that include 21 cumulative inoculations. Data was taken from leaves that developed a hypersensitive response after infiltration with F2/5. A positive response represents complete collapse of infiltrated leaf panel. Intermediate is where only spotty regions of collapse occurred, and negative responses had no collapse.
In most case, the HR and pathogenicity ( $h r p$ ) genes that are associated with the HR encode a proteinaceous elicitor and proteins that are part of the type III secretion system $(3,17)$. Mutations in hrp genes render the bacterium unable to elicit an HR and result in attenuated growth and pathogenicity on the host. Several of the A. vitis mutants described here resemble hrp mutants in that they result in attenuated grape necrosis (pathogenicity) and abolishment of the HR of the nonhost. However, unlike hrp mutants, the A. vitis mutants that were examined do not exhibit a reduced growth character on their grape host, indicating that necrosis is not essential for pathogen growth on the host plant.

The diverse array of phenotypes of the A. vitis mutants on different Vitis spp. suggests that plant species may be responding differently to HR elicitors. For example, the phenotype of mutants M816 (necrosis altered but still able to induce tobacco HR) shows that HR-associated factors alone are not sufficient for necrosis. In contrast, the other mutants that have altered necrosis phenotypes fail to cause HR. Again, these observations are different from what one would expect if $A$. vitis had the classical $h r p$ systems of $P$. syringae pv. syringae or Erwinia amylovora. Mutation in the M675 locus is epistatic to the other loci, because a single mutation knocks out all necrosis and tobacco HR. This phenotype may result if this locus is involved in elicitor secretion, an early step in the synthesis of a family of elicitor molecules, or an essential regulatory function.

There is evidence that some HR-inducing bacteria use mechanisms different from the typical $h r p$ system. For example, the type III system is involved in protein transit through the outer membrane of gram-negative bacteria (10). C. michiganensis subsp. sepedonicus, being gram positive, lacks this membrane and must use a different secretion machinery. Also, the $P$. syringae pv. syringae AvrD elicitor apparently does not require export through a type III secretion apparatus. This protein enzymatically catalyzes production of small-molecule elicitors called syringolides, which induce an HR even when produced in type III secretiondeficient $E$. coli (18).

Thus far, we have sequenced the EcoRI fragment from M6, showing that it contains two ORFs (one in which Tn5 was inserted) that share homology with genes from two marine bacteria, Shewanella spp. and M. marina, that are part of operons encoding long-chain fatty acids. For Shewanella spp., the operon encodes eicosapentaenoic acid (EPA), a highly unsaturated fatty acid, which is an important component of animal cell membranes and is used as a dietary supplement for prevention of several human diseases (21). It is interesting that EPA is also a signal molecule produced by Phytophthora infestans that induces the accumulation of antimicrobial stress metabolites in potato (4). Twenty chain

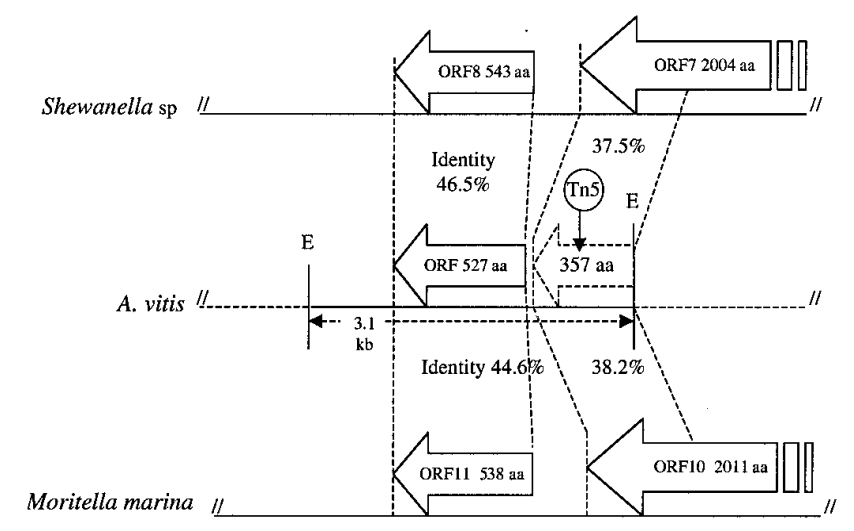

Fig. 6. Map of M6 EcoRI (E) fragment (3,107 bp), denoting a complete and partial open reading frame (ORF) that share homology with known genes from Shewanella sp. and Moritella marina. ORF size, percent identity, direction of transcription, and position of $\operatorname{Tn} 5$ insertion are shown. 
fatty acids such as EPA have not been detected in routine fatty acid profiling of Agrobacterium spp. (5). Whether EPA is produced by $A$. vitis under certain conditions remains to be determined. Further research to determine the nature of HR elicitors that may be produced by $A$. vitis is necessary.

The fact that $A$. vitis induces necrosis on grape roots and crown galls on woody aerial parts of vines is intriguing. Is necrosis associated with $A$. vitis host specificity and does it provide a benefit to the plant (e.g., a defense mechanism) or to the bacterium? It may be that necrosis facilitates systemic colonization of grape or that necrotic tissues provide a niche that excludes other competitive soil microbes. We now have the necessary mutants for studying the genes that control the biochemical processes that are associated with necrosis and HR.

\section{ACKNOWLEDGMENTS}

This research was partially funded by ProfiGen Inc., and M. Thaker was supported by a Merck/AAAS Undergraduate Research Program Grant. We thank S. Farrand, and Z.-Q. Luo, University of Illinois, for assisting us in preparation of the F2/5 DNA library.

\section{LITERATURE CITED}

1. Alfano, J. R., and Collmer, A. 1996. Bacterial pathogens in plants: Life up against the wall. Plant Cell 8:1683-1698.

2. Bauer, D. W., Bogdanove, A. J., Beer, S. V., and Collmer, A. 1994. Erwinia chrysanthemi hrp genes and their involvement in soft rot pathogenesis and elicitation of the hypersensitive response. Mol. PlantMicrobe Interact. 7:573-581.

3. Bonas, U., and Van den Ackerveken, G. 1997. Recognition of bacterial avirulence proteins occurs inside the plant cell: A general phenomenon in resistance to bacterial diseases? Plant J. 12:1-7.

4. Bostock, R. M., and Laine, R. A. 1981. Eicosapentaenoic and arachidonic acids from Phytophthora infestans elicit fungitoxic sesquiterpenes in potato. Science 212:67-69.

5. Bouzar, H., Jones, J. B., and Hodge, N. C. 1993. Differential characterization of Agrobacterium species using carbon-source utilization patterns and fatty acid profiles. Phytopathology 83:733-739.

6. Burr, T. J., Bishop, A. L., Katz, B. H., Blanchard, L. M., and Bazzi, C. 1988. A root-specific decay of grapevine caused by Agrobacterium tumefaciens and A. radiobacter biovar 3. Phytopathology 77:1424-1427.

7. Burr, T. J., and Otten, L. 1999. Crown gall of grape: Biology and disease management. Annu. Rev. Phytopathol. 37:53-80.

8. Burr, T. J., Reid, C. L., Adams, C. E., and Momol, E. A. 1999. Characterization of Agrobacterium vitis strains isolated from feral Vitis riparia. Plant Dis. 83:102-107.

9. Burr, T. J., Reid, C. L., Tagliati, E., Bazzi, C., and Süle, S. 1997. Biological control of grape crown gall by strain F2/5 is not associated with agrocin production or competition for attachment sites on grape cells. Phytopathology 87:706-711.

10. Charkowski, A., Huang, H. C., and Collmer, A. 1997. Altered localization of the HrpZ in Pseudomonas syringae pv. syringae hrp mutants suggests that different components of the type III secretion pathway control protein translocation across the inner and outer membranes of gram-negative bacteria. J. Bacteriol. 179:3866-3874.

11. Chilton, M., Currier, T. C., Farrand, S. K., Bendich, A. J., Gordon, M. P. and Nester, E. W. 1974. Agrobacterium tumefaciens DNA and PS8 bacteriophage DNA not detected in crown gall tumorigenesis. Proc. Natl. Acad. Sci. USA 71:3672-3676.

12. Deng, W., Pu, X., Goodman, R. M., Gordon, M. P., and Nester, E. W. 1995. T-DNA genes responsible for inducing a necrotic response on grape vines. Mol. Plant-Microbe Interact. 8:538-548.

13. Hansen, G. 2000. Evidence for Agrobacterium-induced apoptosis in maize cells. Mol. Plant-Microbe Interact. 13:649-657.

14. He, S. Y., Bauer, D. W., Collmer, A., and Beer, S. V. 1994. Hyper- sensitive response elicited by Erwinia amylovora Harpin requires active plant metabolism. Mol. Plant-Microbe Interact. 7:289-292.

15. Heath, M. C. 1998. Apoptosis, programmed cell death and the hypersensitive response. Eur. J. Plant Pathol. 104:117-124.

16. Herlache, T. C. 1999. Biochemical and molecular genetic investigations of the Agrobacterium vitis-grapevine interaction. Ph.D. thesis. Cornell University, Ithaca, NY.

17. Hueck, C. J. 1998. Type III protein secretion systems in bacterial pathogens of animals and plants. Microbiol. Mol. Biol. Rev. 62:379-433.

18. Keen, N. T., Tamaki, S., Kobayashi, D., Gerhold, D., Stayton, M., Shen, H., Gold, S., Lorang, J., Thordal-Christensen, H., Dahlbeck, D., and Staskawicz, B. 1990. Bacteria expressing avirulence gene D produce a specific elicitor of the soybean hypersensitive reaction. Mol. PlantMicrobe Interact. 3:112-121.

19. Klement, Z., and Goodman, R. N. 1967. The role of the living bacterial cell and induction time in the hypersensitive reaction of the tobacco plant. Phytopathology 57:322-323.

20. Luo, Z.-Q., and Farrand, S. K. 1999. Cloning and characterization of a tetracycline resistance determinant present in Agrobacterium tumefaciens C58. J. Bacteriol. 181:618-626.

21. Needleman, P., Raz, A., Minkes, M. S., Gerrendelli, J. A., and Sprecher, H. 1979. Triene prostaglandins: Prostacyclin and thromboxane biosynthesis and unique biological properties. Proc. Natl. Acad. Sci. USA 76:944-948.

22. Nissinen, R., Lai, F.-M., Laine, M. J., Bauer, P. J., Reilley, A. A., Li, X., De Boer, S. H., Ishimaru, C. A., and Metzler, M. C. 1997. Clavibacter michiganensis subsp. sepedonicus elicits a hypersensitive response in tobacco and secretes hypersensitive response-inducing protein(s). Phytopathology 87:678-684.

23. Otten, L., de Ruffray, P., Momol, E. A., Momol, M. T., and Burr, T. J. 1996. Phylogenetic relationships between Agrobacterium vitis isolates and their Ti plasmid. Mol. Plant-Microbe Interact. 9:782-786.

24. Robinette, D., and Matthysse, A. G. 1990. Inhibition by Agrobacterium tumefaciens and Pseudomonas savastanoi of development of the hypersensitive response elicited by Pseudomonas syringae pv. phaseolicola. J. Bacteriol. 172:5742-5749

25. Rodriguez-Palenzuela, P., Burr, T. J., and Collmer, A. 1991. Polygalacturonase is a virulence factor in Agrobacterium tumefaciens biovar 3. J. Bacteriol. 173:6547-6552.

26. Sambrook, J., Fritsch, E. F., and Maniatis, T. 1989. Molecular Cloning: A Laboratory Manual. 2nd ed. Cold Spring Harbor Laboratory, Cold Spring Harbor, NY.

27. Simon, R., Priefer, U., and Puhler, A. 1983. A broad host range mobilization system for in vivo genetic engineering: Transposon mutagenesis in gram negative bacteria. Bio/Technology 1:784-791.

28. Staphorst, J. L., van Zyl, F. G. H., Strijdom, B. W., and Groenewold, Z. E. 1985. Agrocin-producing pathogenic and nonpathogenic biotype-3 strains of Agrobacterium tumefaciens active against biotype-3 pathogens. Curr. Microbiol. 12:45-52.

29. Tanaka, M., Ueno, A., Kawasaki, K., Yumoto, I., Ohgiya, S., Hoshino, T., Ishizaki, K., Okuyama, H., and Morita, N. 1999. Isolation of clustered genes that are notably homologous to the eicospentaenoic acid biosynthesis gene cluster from the docosahexaenoic acid-producing bacterium Vibrio marinus strain MP-1. Biotechnol. Lett. 21:939-945.

30. Wei, Z.-M., Laby, R. J., Zumoff, C. H., Bauer, D. W., He, S. Y., Collmer, A., and Beer, S. V. 1992. Harpin, elicitor of the hypersensitive response produced by the plant pathogen Erwinia amylovora. Science 257:85-88.

31. Wei, Z.-M., Sneath, B. J., and Beer, S. V. 1992. Expression of Erwinia amylovora Hrp genes in response to environmental stimuli. J. Bacteriol. 174:1875-1882.

32. Yanofsky, M., Lowe, B., Montoya, A., Rubin, R., Krul, W., Gordon, M., and Nester, W. 1985. Molecular and genetic analysis of factors controlling host range in Agrobacterium tumefaciens. Mol. Gen. Genet. 201:237-246.

33. Yazawa, K. 1996. Production of eicosapentaenoic acid from marine bacteria. Lipids 31(suppl.):S297-S300.

34. Zimmerer, R. P., Hamilton, R. H., and Pootjes, C. 1966. Isolation and morphology of temperate Agrobacterium tumefaciens bacteriophage. J. Bacteriol. 92:746-750. 